\title{
Why is chest disease so common in South Wales? Smoking, social class, and lung function: a survey of elderly men in two areas
}

\author{
MICHAEL L BURR AND RUTH M HOLLIDAY \\ From the MRC Epidemiology Unit, 4 Richmond Road, Cardiff CF2 $3 A S$
}

SUMMARY A respiratory survey was conducted in two British towns, one with a high mortality (Caerphilly) and one with a low mortality (Bath) from respiratory disease. A total of 513 men aged 65-74 years were seen. The Caerphilly men had poorer lung function than the Bath men; the overall difference in $\mathrm{FEV}_{1}$ and $\mathrm{FVC}$ for men aged 70 and $1.68 \mathrm{~m}$ tall was 0.161 and 0.171 respectively. These differences appeared to be largely due to the greater tendency of the Caerphilly men to smoke and to an effect related to social class. Respiratory symptoms were also more common in Caerphilly, principally because of the effects of smoking and occupational group, although when these factors were allowed for there was still a significantly greater prevalence of breathless wheezing in Caerphilly.

There is considerable regional variation in the mortality from chest disease in England and Wales. Respiratory mortality in the valleys of South Wales is particularly high, but the reason for this is not known. Possible factors include climatic conditions, occupational history, and the prevalence of smoking. A survey was conducted to compare lung function and respiratory symptoms in elderly men living in areas of high and low risk of respiratory disease. The objective was to see whether any differences existed in lung function and chest symptoms between the two areas and, if so, to what extent such differences could be attributed to smoking and social class.

\section{Subjects and methods}

The two areas studied were Bath and Caerphilly. The male SMR for bronchitis and emphysema in Bath is significantly below the national average, whereas that in Caerphilly is among the top $10 \%$ of local rates. ${ }^{1}$ The subjects selected were men aged 65-74 years, so as to see the effects of long residence in the respective areas. Older men were excluded because of the profound effects of selective mortality among the very old.

There were 4078 and 2789 men in Bath and Caerphilly respectively who were aged $65-74$ years and registered with local general practitioners. A random sample of about 400 names was selected in each area from all the general practitioners' lists. The subjects were asked to attend a clinic; those not able to attend were seen at home. A short questionnaire (including the standard MRC questions on cough and phlegm) was completed for each man and his height and weight were measured. Five $\mathrm{FEV}_{1}$ and three FVC measurements were made using a McDermott Spirometer; ${ }^{2}$ the means of the three highest $\mathrm{FEV}_{1}$ and of all three FVC readings were taken as the true values. Adjustments to BTPS were made automatically by the spirometer from an assumed spirometer temperature of $20^{\circ} \mathrm{C}$; further adjustments were not made, partly because of doubts as to the value of this procedure ${ }^{3,4}$ and partly because the spirometer temperature in fact varied little from $20^{\circ} \mathrm{C}$ throughout the survey.

\section{Results}

Table 1 shows the numbers of men selected and seen in Bath and Caerphilly. We have reason to think that those untraced had mostly died or left the area although they were still on the general practitioners' lists. The response rates are therefore shown in relation to those traced and are similar in the two areas.

Table 2 shows the height, body mass, and lung function measurements of the men in the two areas. Here and in subsequent tables the men are classified according to their last main occupation; those in social classes I to IIINM are classified as non-manual while the rest are manual workers. The non-manual workers were taller than the manual workers in each area and the Bath men were taller than the corresponding Caerphilly men, by about $2 \mathrm{~cm}$ in each case. 
Table 1 Numbers of subjects selected and seen

\begin{tabular}{|c|c|c|}
\hline & Bath & Caerphilly \\
\hline Total no. drawn in sample & 400 & 403 \\
\hline Already dead & 12 & 22 \\
\hline Outside area & 11 & 15 \\
\hline Untraced & 17 & 15 \\
\hline Wrong age & 6 & 5 \\
\hline Female & 1 & 0 \\
\hline Duplicates & 0 & 18 \\
\hline Total ineligible for survey & 47 & 75 \\
\hline Total eligible for survey & 353 & 328 \\
\hline In hospital or too ill & 6 & 8 \\
\hline Refusals and other non-responders & 80 & 74 \\
\hline Seen in survey & 267 & 246 \\
\hline$\%$ of eligible subjects seen & $75 \cdot 6$ & $75 \cdot 0$ \\
\hline
\end{tabular}

$\mathrm{FEV}_{1}$ and FVC were standardised for height using the method advocated by Cole; ${ }^{5}$ each man's FEV ${ }_{1}$ and FVC was divided by the square of his height in metres and the result was multiplied by $1.68^{2}$ to give the adjusted value for a height of $1.68 \mathrm{~m}$. A further small adjustment was made for age; since there were no significant differences between the gradients of lung function with age in the four groups, the average slope was used $(-0.013$ per year, corresponding to an annual decline of 0.041 in FEV 1 and FVC). The resulting values, adjusted to a height of $1.68 \mathrm{~m}$ and age 70 years, are referred to as $\mathrm{FEV}_{1}{ }^{*}$ and $\mathrm{FVC}^{*}$ respectively. There is a small residual association between these adjusted values and height, due apparently to the fact that $\mathbf{k}$ (the power of height in Cole's formula) should be slightly greater than 2 . The differences made by increasing the value of $k$ are only marginal, however, and do not affect any of the conclusions of the survey, so the value has been taken as 2 so as to preserve comparability with other data analysed in this way.

There were two men (both Caerphilly manual workers) for whom the data are incomplete. One was unable to perform the lung function tests at all. The other was unable to stand and so was not measured; in consequence his $\mathrm{FEV}_{1}{ }^{*}$ and $\mathrm{FVC}^{*}$ could not be calculated, so that only his $\mathrm{FEV}_{1} / \mathrm{FVC}$ ratio is included here.

The overall mean $\mathrm{FEV}_{1}{ }^{*}$ was significantly higher $(p<0.01)$ in Bath than in Caerphilly (2.161 and 2.00 1), and so was the overall mean FVC* $(3.191$ and 3.04 1 respectively, $\mathrm{p}<0.05) . \mathrm{FEV}_{1}{ }^{*}$ and $F V \mathrm{CV}^{*}$ and the FEV 1 / FVC ratio were all higher in non-manual workers than in manual workers in both areas. All these data were recalculated after excluding men who had lived for less than 10 years in their respective area (20 in Bath, 24 in Caerphilly), but no material changes resulted so these men are included.

Table 3 shows the prevalence of various conditions in the two areas as reported by the subjects themselves. Cigarette smoking was much commoner in Caerphilly

Table 2 Height, body mass, and standardised lung function

\begin{tabular}{|c|c|c|c|c|c|c|c|c|c|c|c|c|c|}
\hline & \multirow[t]{2}{*}{ No. } & \multicolumn{2}{|c|}{ Age (yr) } & \multicolumn{2}{|c|}{ Height (m) } & \multicolumn{2}{|c|}{ Body mass $\left(\mathrm{kg} / \mathrm{m}^{2}\right)$} & \multicolumn{2}{|c|}{$F E V_{1}^{*}$} & \multicolumn{2}{|l|}{$F V C^{*}$} & \multicolumn{2}{|c|}{$F E V_{I} / F V C$} \\
\hline & & Mean & $(S D)$ & Mean & $(S D)$ & Mean & $(S D)$ & Mean & $(S D)$ & Mean & (SD) & Mean & $(S D)$ \\
\hline Non-manual & 140 & 68.9 & $(2 \cdot 7)$ & 1.72 & $(0 \cdot 06)$ & $25 \cdot 4$ & $(2.9)$ & $2 \cdot 30$ & $(0.63)$ & $3 \cdot 32$ & $(0 \cdot 70)$ & 0.69 & $(0 \cdot 12)$ \\
\hline Manual & 127 & $69 \cdot 6$ & $(2 \cdot 6)$ & 1.70 & $(0.07)$ & $25 \cdot 6$ & $(3 \cdot 7)$ & 2.01 & $(0.62)$ & 3.04 & $(0.70)$ & 0.66 & $(0 \cdot 12)$ \\
\hline All subjects & 267 & $69 \cdot 3$ & $(2 \cdot 7)$ & 1.71 & $(0.07)$ & $25 \cdot 5$ & $(3 \cdot 3)$ & $2 \cdot 16$ & $(0.64)$ & $3 \cdot 19$ & $(0.71)$ & 0.68 & $(0 \cdot 12)$ \\
\hline \multicolumn{14}{|l|}{ Caerphilly men } \\
\hline Non-manual & 60 & $69 \cdot 4$ & $(2 \cdot 9)$ & $1 \cdot 70$ & $(0.06)$ & $26 \cdot 0$ & $(3 \cdot 7)$ & $2 \cdot 13$ & $(0.60)$ & $3 \cdot 13$ & $(0 \cdot 69)$ & 0.68 & $(0 \cdot 11)$ \\
\hline Manual & $186 t$ & $69 \cdot 6$ & $(2.6)$ & 1.68 & $(0.06)$ & $25 \cdot 4$ & (3.9) & 1.96 & $(0.63)$ & 3.01 & $(0.71)$ & 0.65 & $(0 \cdot 13)$ \\
\hline All subjects & 246 & $69.5 i$ & $(2 \cdot 7)$ & 1.68 & $(0.07)$ & $25 \cdot 6$ & (3.8) & 2.00 & $(0.63)$ & 3.04 & $(0.71)$ & 0.65 & $(0 \cdot 13)$ \\
\hline
\end{tabular}

- Adjusted to age $70 \mathrm{yr}$ and height $1.68 \mathrm{~m}$

t Data incomplete in two subjects (see text)

Table 3 Prevalence of certain conditions in two areas

\begin{tabular}{|c|c|c|c|c|c|c|c|c|}
\hline & \multirow[t]{2}{*}{ No. } & \multirow[b]{2}{*}{$\begin{array}{l}\text { Current } \\
\text { cigarette } \\
\text { smokers }\end{array}$} & \multicolumn{6}{|c|}{ Percentage reporting history of certain conditions } \\
\hline & & & $\begin{array}{l}\text { Coronary } \\
\text { thrombosis }\end{array}$ & Asthma & $\begin{array}{l}\text { Pulmonary } \\
\text { tuberculosis }\end{array}$ & $\begin{array}{l}\text { Chronic } \\
\text { bronchitis }\end{array}$ & Emphysema & $\begin{array}{l}\text { Recent chest } \\
\text { treatment }\end{array}$ \\
\hline \multicolumn{9}{|l|}{ Bath men } \\
\hline $\begin{array}{l}\text { Non-manual } \\
\text { Manual }\end{array}$ & $\begin{array}{l}140 \\
127\end{array}$ & $\begin{array}{l}21 \% \\
25 \%\end{array}$ & $\begin{array}{l}8 \% \\
6 \%\end{array}$ & $\begin{array}{l}3 \% \\
8 \%\end{array}$ & $\begin{array}{l}1 \% \\
2 \%\end{array}$ & $\begin{array}{r}4 \% \\
15 \%\end{array}$ & $\begin{array}{l}2 \% \\
1 \%\end{array}$ & $\begin{array}{l}14 \% \\
29 \%\end{array}$ \\
\hline \multicolumn{9}{|l|}{ Caerphilly men } \\
\hline $\begin{array}{l}\text { Non-manual } \\
\text { Manual }\end{array}$ & $\begin{array}{r}60 \\
186\end{array}$ & $\begin{array}{l}38 \% \\
41 \%\end{array}$ & $\begin{array}{r}10 \% \\
8 \%\end{array}$ & $\begin{array}{l}5 \% \\
6 \%\end{array}$ & $\begin{array}{r}12 \% \\
3 \%\end{array}$ & $\begin{array}{l}22 \% \\
27 \%\end{array}$ & $\begin{array}{r}8 \% \\
12 \%\end{array}$ & $\begin{array}{l}23 \% \\
31 \%\end{array}$ \\
\hline
\end{tabular}

* Recent chest treatment-treatment for chest within past 12 months. 
than in Bath, with little difference between manual and non-manual workers in either area. Reported chest disease tended to be more common in Caerphilly than in Bath; the Caerphilly non-manual men reported much more pulmonary tuberculosis than did the other groups.

Table 4 shows the mean $\mathrm{FEV}_{1}$ * values for the men classified by area, occupation, and smoking history. There is still a difference between non-manual and manual workers, the latter tending to have the lower FEV $_{1}{ }^{*}$ values. But there is now no consistent difference between Bath and Caerphilly men within occupational and smoking groups. The mean FVC* values show a very similar pattern. These observations were confirmed by a multiple linear regression analysis of lung function on smoking (categorised as in table 4), area, and occupational group; once the effects of smoking and occupation were allowed for there was no significant difference between the two areas for FEV $_{1}{ }^{*}$, FVC $^{*}$ or FEV $/ F V C$ ratio. There were no significant differences in lung function between neversmokers, current cigar and pipe smokers, and those who had ceased smoking 10 or more years ago; or between current cigarette smokers and those who ceased smoking within 10 years.

Table 5 shows the prevalence of symptoms of cough and phlegm (on most days for as much as three months each year) and of breathless wheezing (a history of wheezing during the past year associated at least once with breathlessness). Overall, these symptoms were commoner in Caerphilly than in Bath, but this seemed to be due mostly to a greater tendency to smoke in Caerphilly. The interrelation between these smoking categories, occupational groups, and symptoms was further investigated by means of logit analysis. Occupational group and smoking history accounted for significant amounts of the variance for each of the three symptoms. Cough was particularly associated with current cigarette smoking, area being unimportant once occupation and smoking were accounted for. Phlegm was related to any history of smoking, past or present; area explained a small additional amount of variance but the relation did not approach statistical significance. Breathless wheezing

Table $4 F E V_{1}^{*}$ in smokers and non-smokers

\begin{tabular}{|c|c|c|c|c|c|}
\hline & \multicolumn{5}{|c|}{ Smoking category } \\
\hline & Never smoked & Stopped $\geqslant 10 \mathrm{yr}$ & Stopped $<10 \mathrm{yr}$ & Cigarette smokers & Pipe/cigar smokers \\
\hline $\begin{array}{l}\text { Bath non-manual } \\
\text { No. } \\
\text { Mean FEV } \\
\text { * (SD) }\end{array}$ & $2.63^{21}(0.48)$ & $2.45^{52}(0.58)$ & $1.91^{15}(0.74)$ & $1.89^{30}(0.62)$ & $2.47^{22}(0.38)$ \\
\hline $\begin{array}{l}\text { Bath manual } \\
\text { No. } \\
\text { FEV }^{*} \text { (SD) }\end{array}$ & $2.26^{20}(0.45)$ & $2.25^{38}(0.70)$ & $1.64^{22}(0.47)$ & $1.83^{32}(0.49)$ & $2.02^{15}(0.73)$ \\
\hline $\begin{array}{l}\text { Caerphilly non-manual } \\
\text { No. } \\
\text { Mean FEV }{ }_{1}^{*} \text { (SD) }\end{array}$ & $2 \cdot 11^{12}(0.37)$ & $2.42^{12}(0.67)$ & $1.51{ }^{6}(0.38)$ & $2.06^{23}(0.58)$ & $2.41^{7}(0.71)$ \\
\hline $\begin{array}{l}\text { Caerphilly manual } \\
\text { No. } \\
\text { Mean FEV } \text { l }^{*} \text { (SD) }\end{array}$ & $2.26^{25}(0.50)$ & $2.03^{36}(0.68)$ & $1.74^{29}(0.70)$ & ${ }_{1.86}^{75}(0.57)$ & $2.17^{19}(0.66)$ \\
\hline
\end{tabular}

Table 5 Prevalence of symptoms in smokers and non-smokers

\begin{tabular}{|c|c|c|c|c|c|c|}
\hline & \multicolumn{6}{|c|}{ Smoking category } \\
\hline & Never smoked & Stopped $\geqslant 10 \mathrm{yr}$ & Stopped $<10 \mathrm{yr}$ & Cigarette smokers & Pipe/cigar smokers & All men \\
\hline \multicolumn{7}{|l|}{ Bath men } \\
\hline No. & 41 & 90 & 37 & 62 & 37 & 267 \\
\hline$\%$ with cough & 15 & 19 & 24 & 39 & 14 & 23 \\
\hline$\%$ with phlegm & 7 & 18 & 24 & 25 & 19 & 19 \\
\hline$\%$ with breathless wheezing & 10 & 17 & 35 & 42 & 5 & 22 \\
\hline \multicolumn{7}{|l|}{ Caerphilly men } \\
\hline No. & 37 & 49 & 35 & 99 & 26 & 246 \\
\hline$\%$ with cough & 16 & 35 & 29 & 39 & 23 & 32 \\
\hline$\%$ with phlegm & 11 & 35 & 29 & 38 & 27 & 31 \\
\hline$\%$ with breathless wheezing & 32 & 39 & 43 & 43 & 23 & 39 \\
\hline
\end{tabular}


was associated with recent (within 10 years) and current cigarette smoking; the variance due to area was just significant $(p<0.05)$ when smoking and occupational group were allowed for.

Although this survey was not set up to study the effects of coalmining, in view of the importance of this industry in Caerphilly it seemed reasonable to examine separately the data from Caerphilly manual workers who had never been miners. There were 68 of these men; their mean $\mathrm{FEV}_{1}{ }^{*}(1.981), \mathrm{FVC}^{*}(2.971)$, and prevalence of current smoking $(\mathbf{4 4} \%)$ were very similar to the corresponding values for the whole group of Caerphilly manual workers.

\section{Discussion}

The valleys of South Wales are notorious for chest disease. The male standardised mortality ratio 196878 for bronchitis and emphysema in Caerphilly is 163, whereas that in Bath is 76 , the $95 \%$ confidence intervals being $143-185$ and $68-85$ respectively (MJ Gardner, personal communication). The high respiratory mortality of the South Wales valleys has not been satisfactorily explained; possible explanations include the weather (which tends to be cold and damp), atmospheric pollution, an industrial history of coalmining associated with pneumoconiosis, and selective migration out of the area by the healthier persons. This survey was undertaken to compare elderly men in the two areas to see whether the differences in respiratory mortality are reflected in lung function and respiratory symptoms, and to what extent such differences can be attributed to some of the factors that are known or believed to cause respiratory damage.

It is clear from this study that elderly men in Caerphilly have more respiratory symptoms and poorer lung function than their contemporaries in

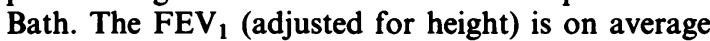
$0 \cdot 161$ less at age 70 years, corresponding to the decline that occurs over about four years in this age group. The lower values in Caerphilly are apparently attributable to two main factors, smoking and occupational class.

Smoking is the most important known factor affecting lung function and continues to exert an effect into old age. ${ }^{6}$ The Caerphilly men have a substantially higher percentage of current smokers than those in Bath. The effect of social class is clear: in both areas the manual workers have a poorer lung function and more symptoms than the non-manual. The reason for this is not obvious; it cannot be simply due to coalmining, since the same trend occurred in Bath where there were virtually no miners. Standardised mortality ratios for respiratory disease in men aged 15-64 show a similar effect of occupation, rising from
37 in social class I to 187 in social class $V .^{7}$ The lower lung function of manual workers may be partly due to poorer housing conditions and other general disadvantages of lower social class which operate over a lifetime, including childhood experience of respiratory disease, which is associated geographically with chronic bronchitis mortality. ${ }^{8}$ The higher prevalence of symptoms in Caerphilly was largely explicable in terms of smoking and occupational group. Breathless wheezing did, however, have an independent significant association with area, possibly attributable to the damper climate or other local features of Caerphilly. This is consistent with the findings of a nationwide survey of respiratory symptoms in the UK; breathlessness and wheezing were markedly commoner in Wales even after other factors (including smoking and social class) were allowed for. ${ }^{9}$ In another survey, the incidence of bronchitis among children and adults was higher in South Wales than in other areas with similar degrees of atmospheric pollution. ${ }^{10}$ It may also be relevant that, in an earlier survey in Caerphilly, wheezing was associated with dampness and open coal fires, which are characteristic of South Wales. ${ }^{11}$

Certain potential sources of bias must also be considered. Migration into the areas may have diluted any specifically local effects and is likely to have brought in healthy rather than unhealthy individuals. But, in fact, few men had lived for less than ten years in either town, their numbers were similar in Bath and Caerphilly, and omitting them did not affect the results. We have no information about migration out of these areas, which is likely to have removed fit rather than unfit persons; if it occurred more in Caerphilly than in Bath it could have exaggerated the difference between the mortality rates. But the current elderly inhabitants of the two towns were indistinguishable in regard to lung function when smoking and social class were allowed for, so selective migration probably had little overall effect. The higher death rates in Caerphilly may have removed proportionately more men than in Bath before the age of 65 years, so that those who survived to that age may not represent all those who were originally their contemporaries to an equal degree in the two towns. But relatively few people die under the age of 65 years, so the distorting effects of differential mortality rates are unlikely to be very great within the age group studied.

In view of the similarity of the lung function of subjects of comparable smoking history and social class in the two areas, additional factors probably contribute little to the area differences in respiratory mortality, although they may cause or aggravate certain symptoms. It therefore seems reasonable to conclude that the bad reputation of the Welsh valleys 
for chest disease is due largely to the smoking habits of the residents, plus an effect associated with social class.

\section{References}

${ }^{1}$ Gardner MJ, Winter PD, Barker DJP. Atlas of mortality from selected diseases in England and Wales 1968-1978. Chichester; John Wiley \& Sons Ltd, 1984.

${ }^{2}$ McDermott M, McDermott TJ, Collins MM. A portable bellows spirometer and timing unit for the measurement of respiratory function. Medical and Biological Engineering 1968; 6: 291-302.

${ }^{3}$ Perks WH, Sopwith T, Brown D, Jones CH, Green M. Effects of temperature on Vitalograph spirometer readings. Thorax 1983; 38: 592-4.

${ }^{4}$ Cramer D, Peacock A, Denison D. Temperature corrections in routine spirometry. Thorax 1984; 39: $771-4$.
${ }^{5}$ Cole TJ. Linear and proportional regression models in the prediction of ventilatory function. J $R$ Stat Soc Ser $A$. 1975; 138: 297-338.

${ }^{6}$ Burr ML, Phillips KM, Hurst DN. Lung function in the elderly. Thorax 1985; 40: 54-59.

${ }^{7}$ Office of Population Censuses and Surveys. Occupational mortality: the Registrar General's decennial supplement for England and Wales 1970-72. London; HMSO, 1978.

8 Barker DJP, Osmond C. Childhood respiratory infection and adult chronic bronchitis in England and Wales. $\mathrm{Br}$ Med J 1986; 293: 1271-5.

${ }^{9}$ Dean G, Lee PN, Todd GF, Wicken AJ, Sparks DN. Factors related to respiratory and cardiovascular symptoms in the United Kingdom. $J$ Epidemiol Community Health 1978; 32: 86-96.

${ }^{10}$ Colley JRT, Reid DD. Urban and social origins of childhood bronchitis in England and Wales. Br Med J 1970; 2: 213-7.

11 Burr ML, St. Leger AS, Yarnell JWG. Wheezing, dampness, and coal fires. Community Medicine 1981; 3: 205-9. 